औis:

TRANS · núm. I9.2 2015

ARTICULOS · 243-262
This article offers a new interpretation of the forty-seven Aesop's fables that were anonymously translated from Latin into classical Nahuatl in colonial Mexico. Informed by former studies that have pointed at the Nahua students and tutors of the sixteenth-century Imperial College of Tlatelolco as the most likely translators, this study elaborates on their educational environment and tries to explain how they might have learnt Latin by following the exercises that Quintilian suggested in Institutio oratoria for the paraphrase of Aesop's fables. In addition, the article explores the hybrid nature of the Nahuatl version, acknowledging its indigenous rhetorical style, as indicated by Gordon Brotherston, and at the same time highlighting the translator(s)' Christian manipulation of the Aesopic tradition. In fact, an overall analysis of the fables seeks to demonstrate that they must have been translated in order to function as stories or exempla for conversion purposes.

KEY WORDS: Aesop, Nahua translators, College of Tlatelolco, evangelization

\title{
The Translation of Aesop's Fables in Colonial Mexico
}

\author{
VICTORIA Ríos CASTAÑO \\ Newcastle University
}

\section{La traducción de las fábulas de Esopo en el México colonial}

Este artículo ofrece una nueva interpretación de las cuarenta y siete fábulas de Esopo traducidas anónimamente del latín al náhuatl clásico en el México colonial. Partiendo de estudios previos que habían señalado a estudiantes y tutores nahuas del siglo XVI del Colegio de la Santa Cruz de Tlatelo/co como los probables traductores, este estudio indaga en su ámbito educativo e intenta explicar el método de aprendizaje del latín que seguía los ejercicios que sugería Quintiliano en su Institutio oratoria para parafrasear las fábulas de Esopo. Se explora además la naturaleza hibrida de la versión en náhuatl, al reconocer, por un lado, la retórica indígena de su estilo, indicado por Gordon Brotherston, como al destacar la manipulación del o los traductores cristianos en la transmisión de las fábulas. De hecho, se trata de un análisis completo de las fábulas que aspira a demostrar que deben haber sido traducidas con el fin de funcionar como historias o exempla para propósitos de conversión.

palabras clave Esopo, Traductores nahua, Colegio de la Santa Cruz de Tlatelolco, evangelización. 


\section{INTRODUCTION}

The translation of Aesop's fables from Latin into classical Nahuatl has hardly drawn criti244 cal attention since the Mexican scholar Angel María Garibay Kintana denied them of any interest in his seminal Historia de la literatura nábuatl (1953-I954), with Gordon Brotherston and Günter Vollmer's I987 edition containing the only two studies available to curious readers and experts on colonial America. ${ }^{\mathrm{T}}$ Their hypothesis and conclusions stand as follows. The forty-seven fables that have survived are a reminder of many other hand-written copies that must have circulated among a wide audience of indigenous speakers. ${ }^{2}$ For the date of composition of the fables, Garibay Kintana suggested the second half of the sixteenth century and, possibly because of the other doctrinal works that were found accompanying the manuscripts, he pointed at the Franciscan missionary Fray Bernardino de Sahagún as the likely translator (Vollmer, I987: 222-223). ${ }^{3}$ Having arrived in New Spain in 1529, Sahagún spent most of his life dedicated to the schooling of the Nahua elite's sons and to the com-

\footnotetext{
I Brotherston reiterated the contents of his study in I992: 315-319.

2 There are only two extant manuscripts of said translation. The one edited by Brotherston and Vollmer belongs to the Bancroft library of Berkeley, whereas the second, with very slight deviations if compared to that of the Bancroft library, is catalogued in the Biblioteca Nacional of México (Vollmer, I987: 217, 23I). A I80os copy by the Mexican priest and scholar José Antonio Pichardo, who probably attached a Latin version to the first thirty-three fables in order to present readers with a parallel-text format, is held in the Bibliothèque Nationale of Paris, and can be accessed online at http://amoxcalli.org. $\mathrm{mx} /$ paleografia $\cdot$ php?id $=28 \%$.

3 The Biblioteca Nacional manuscript comprises, among others, two works attributed to Sahagún - the Kalendario and the Arte adivinatoria. The Bancroft library one includes a Santoral; a calendar of saints' days, and a collection of Nahua sayings and metaphors (Vollmer, 1987: 209, 2II).
}

position of proselytizing works in Nahuatl. Unable to prove the authorship of the Nahuatl fables, the anthropologist Gerdt Kutscher, who was first to translate them into German, was similarly convinced that these imbibed from Sahagún's intellectual environment. They were, as Vollmer (1987: 235) quotes Kutscher, "proof of an occidental intelligence, with which the great Sahagún paid his thanks to the Indians for sharing so much of their culture with him." Conversely, in his preliminary study of their joint edition of the fables, Brotherston takes issue with this statement, arguing instead that it was the "Indians" to whom Kutscher alluded who worked as the translator(s) of the fables and as copyists of the manuscripts, for only native speakers were able to compose such a refine and fluent text in the Nahuatl language. Brotherston (1987: 27) is equally certain that the translator(s) found inspiration in their pre-Hispanic cultural heritage and that, more specifically, their tonalamatl, a divinatory calendar composed of animal signs, "formed a precise antecedent" in their rendering of the Aesopic tradition. Departing from any connection with a religious context and from the possibility that the fables had been translated by churchmen or under their direction, Brotherston's contention remains oriented toward their unique indigenous nature, asserting (1992: 316) that they do not bear much "resemblance to the Nahuatl catechisms and Bible stories produced by the friars and their local helpers."

Although agreeing with Brotherston on the indigenous rhetorical nature of the Nahuatl version, the intention of this study, nonetheless, is to offer an additional reading and demonstrate that the fables resonate with a pre-Hispanic past and also with a strong Christian skew. In proving so, this article is divided into three main sections. The first begins with an overview of 
the Aesopic tradition in Europe so as to advance how Aesop's fables were transposed as an educational and liturgical source in the New World, specifically in Colonial Mexico. The second explores the link between the Nahuatl fables and the Franciscan Imperial College of Santa Cruz of Tlatelolco, entertaining the possibility that the Nahua translator(s) were connected with this institution, as suggested by José María Kobayashi (1974: 365-386) and Michael Mathes (1982: 26). The section briefly examines the translator(s)' educational context by looking at the manner in which they might have learnt Latin, and considers some examples of domestication that are inserted in the translation of the fables into Nahuatl. Elaborating on the translator(s)' rhetorical knowledge of their mother tongue and on their Christian environment, the third section of the article continues to delve into their interpretation of the source text and brings to the fore the doctrinal purposes that appeared to have dictated the writing of the translation in the first place. All in all, the fables in the Nahuatl language are contextualized within a religious setting, where some of the Nahuas who had been educated in a Christian institution became indispensable for the composition of works that were deployed in religious communications with Nahua neophytes.

\section{AESOP'S FABLES FOR EDUCATIONAL AND LITURGICAL PURPOSES}

In Book I of Institutio oratoria (The education of the orator; ca. A. D. 95), the classical twelvebook manual of rhetoric that, concerned with the formation of a citizen-orator, unites a teaching guide on education and a reflection on moral duties, Quintilian urges teachers to initiate their students into certain "rudiments of oratory" and virtuous conduct by means of a series of speaking, reading, and writing activities (Murphy, 1987: xviii-xix). One of these, the "paraphrase [of] Aesop's fables" (Quintilian, I922: 159) is accomplished thanks to the completion of three consecutive tasks. ${ }^{4}$ The pupils, Quintilian (1922: 159) explains,

should begin by analysing each verse, then give its meaning in different language, and finally proceed to a freer paraphrase in which they will be permitted now to abridge and now to embellish the original, so far as this may be done without losing the poet's meaning.

As observed in this passage, Quintilian's suggested exercises do not substantially differ from some of those carried out in present-day teaching scenarios. Firstly, Quintilian proposes the reading comprehension of a fable, which requires an analysis of its vocabulary and grammar; secondly, a literal translation into a "different language"-in his own time most likely from Greek verse into Latin-; and finally, a "freer paraphrase" or appropriation of the text by indulging into a free translation, that is to say, into the rewriting of the original source, which allows the student to shorten or to extend the fable as long as its original meaning is respected.

The Aesopic literary tradition, so-called due to the complex process of appropriations

4 The moral stories revolving around human and animal subjects that have been attributed to Aesop - a historical figure of the island of Samos who is thought to have lived around 2,80o-2,60o years ago- originally constituted a Greek body of adult popular knowledge that was told in private conversations and public events like assemblies and dinner parties (Gibbs, 2008: xi). The Greek poet Hesiod authored the first written testimony in the eighth century B.C., and the first extant collection of fables, this time in Latin verse, was composed by Phaedrus in the first century A.D. To this compilation followed many others, such as the anonymous Collectio Augustana (third-century), in Greek verse; the one by Aphthonius (fourth-century), in Greek prose; and that of Avianus (ca. fifth century), in Latin verse. 
and rewritings with which the fables were fraught over the centuries, made its way into the classical and religious studies of the middle 246 Ages. The fables formed part of two textbooks that students of Latin read once they had achieved a satisfactory mastery of grammar: the Sex auctores, widely-circulated up to the thirteenth century, and its sequel, the Auctores octo morales, which had strong influence well into the Renaissance. The former compiled stories by six classical authors, like Theodulus, Maximianus, Claudian, Cato, and the version of Aesop's fables written by Avianus. The latter, placing major emphasis upon the teaching of Christian moral values, consisted of a book of schoolboys' manners, parables, and retellings of biblical stories, and at the same time kept some of the texts of the Sex auctores, such as Aesop's fables, this time as written by Walter the Englishman (ca. r200) (Ciccolella, 2008: 68; Orme, 2006: 99-10I). Avianus and Walter's collections competed with several versions of the fables during the medieval period. From the tenth-century onwards, the Aesopic tradition favoured a compilation known under the name of "Romulus"-which contained Phaedrus's Latin fables transformed into prose-, and which coexisted with other collections, like the French monk Ademar of Chabannes's (eleventh century) and the humanist Bonus Accursius'; the Collectio Accursiana (fifteenth-century). The fables also reached the Renaissance, alluded to in Alciato's Emblems and Erasmus's Adages, and outsourced by authors who retold old and new stories as they were passed on among the population through word of mouth (Gibbs, 2008: i-xii; xx-xxix, xl-xli)

While some collections of fables, as in the case of Avianus and Walter's, were drawn on by tutors as minor reading for pedagogical purposes, other collections transferred the Aesopic

tradition to an evangelical, liturgical context. Together with legends, contemporary events, and the descriptions of animals in bestiaries, the fables became exempla in popular preaching; short stories that aided in the transmission of oral and folkloric memories and bridged the intellectual gap between churchmen and commoners. Aesop's stories were pronounced by preachers in order to retain or regain their audience's interest as well as to facilitate the understanding of an intricate moral or theological exposition (Taylor, 1992: 68, Barry, 2004: 83). The edition of the fables by the thirteenth-century scholar and cleric Odo of Cheriton illustrates the manner in which churchmen consulted these in order to stimulate moral improvement. In the hands of a preacher in search of exempla that conveyed a specific message or moral Cheriton's compilation proved very reader-friendly. First, he organized the fables in thematic groups by, for instance, grouping together stories dealing with the election of a ruler or a king. Second, he framed the body of the text, that is, the fable itself, with a promythium - a brief interpretation of the meaning of the text-and an epimythium-the conclusion or moral of the story (Gibbs, 2008: xxviii-xxix). Cheriton's adaptation of "The crow, the eagle and the feathers", in which a group of birds spruced up the crow with their feathers, emerges as a prime example of a fable-exemplum that could be harnessed to condemn vanity and ingratitude. Cheriton starts the fable with the promythium "a fable against people who boast that they have something they do not" (Gibbs, 2008: xxviii), and at the foot of the text he adds his own epimythium: "This fable can also be used against wealthy men who boast of the extent of their riches: The Lord will take everything in time and thus the rich are humiliated" (Gibbs, 2008: xxviii). Instead of reading 
the fable in its entirety, a preacher could scan these lines at the beginning and the end of the text, which made the identification of an appropriate fable less time-consuming. Thus, when wishing to extract an exemplum on vanity and ingratitude he could have chosen "The crow, the eagle and the feathers", and referred to it during the delivery of his sermon to a large congregation comprising individuals of all walks of life and social status. ${ }^{5}$

\section{AESOP'S FABLES IN THE IMPERIAL COLLEGE OF SANTA CRUZ OF TLATELOLCO}

The twofold deployment of the Aesopic tradition in Europe-for the teaching and learning of Latin and moral values, and for an easier exposition of the Christian doctrine-, ensured that Aesop's fables found their way to the libraries of New World friaries and schools. In colonial Mexico in particular, the fables have been recorded in sixteenth and seventeenth-century catalogues like those of the Friary of Toluca and the College of Tlatelolco (Mathes, I982: 33; Gómez Canedo, I98I-1982: 69). The latter, formally inaugurated in 1536 , functioned as a centre of study for the Franciscans and as a secondary grammar school for the male Nahua elite. The schoolboys, who started aged ten to twelve, were instructed for three years in the subjects of the Trivium and the Quadrivium, together with moral and natural philosophy and Christian doctrine (Kobayashi, 1974: 277, Mathes, I982: 23). Some of the tutors of the college, aside from performing their teaching and pastoral

5 For further reference on Cheriton's use of animal tales in his sermons, see Joyce Salisbury's study of animals as human exemplars during the medieval period (2OI2: 97-99). duties, were active in a number of proselytizing endeavours; not only in the continuation of their religious studies, but also in the administering of the sacraments and the production of 247 auxiliary works for conversion in the Nahuatl language. Thus, Fray Arnaldo de Bassacio, the first to teach Latin, composed sermons and brief doctrinal treatises; Fray Juan Focher, who imparted rhetoric, logic, and natural and moral philosophy, composed a Nahuatl grammar, and Fray Bernardino de Sahagún, who taught Latin and moral and natural philosophy, directed the creation of several proselytizing works (Mendieta, 1973, II: 280, 195). ${ }^{6}$ Although attributed to the friars, the production of these texts relied heavily on those pupils who had proven to be the most advanced. Sahagún (1988, II: 635) reports on their linguistic expertise and on the activities in which they were involved in the following manner:

$[\mathrm{N}]$ os dan a entender las propriedades de los vocablos y las propriedades de su manera de hablar, [examinan y corrigen] las incongruidades que hablamos en los sermones o escrebimos en las doctrinas [...] [.] [C]ualquiera cosa que se ha de convertir en su lengua, si no va con ellos examinada, no puede ir sin defecto, escrebir congruamente en la lengua latina ni en romance ni en su lengua.

The passage offers a portrayal of Nahua students, later assistants and even tutors of the college, who proofread and wrote texts, translated, and interpreted in three languages; Nahuatl, Latin, and Spanish. In this sense, and

\footnotetext{
6 Among these texts can be cited an encyclopaedic work on the Nahuas, Historia universal de las cosas de Nueva España (ca. 1577), and sermons and psalms like those of Psalmodia christiana y sermonario de los sanctos del año (I583). For an analysis of these texts, see Anderson I993, Bustamante García I989 and I990, and Ríos Castaño 2014.
} 
stressing their high skill in the performance of these duties, Sahagún takes pride that his assistants became "gramaticos" and "trilingues"-by 248 which he probably means that they were native speakers of Nahuatl with an excellent command of Latin and Spanish (Sahagún, 1950-1982: $53-55)$. The catalogue of the college records the works thanks to which they might have attained this linguistic mastery. For the study of Latin grammar and rhetoric, the Nahua assistants would have attended classes in which tutors availed themselves of Nebrija's Introductiones latinae and of a copious list of collections and works by classical authors, including Cicero, Virgil, Pliny, Seneca, Sallust, Juvenal, Livy, Cato, Caesar, Plutarch, and Aesop (Mathes, I982: 32-33, 35, 47-77, 93-96). Many of these were suggested readings by Quintilian, whose textbook was also present in the library. In fact, the imitation and paraphrase of passages within these texts might have been part of the Nahuas' training, and in this respect Sahagún (I988, II: 634) praises the ability of his students when claiming that they became quickly adept at the composition of "versus heruicus;" the English iambic pentameter that is found in another work recommended by Quintilian; Virgil's The Aeneid. 7

The survival of some of these heroic verses could have contributed to shed some light upon the manner in which Sahagún's Nahua students were trained to grasp, consolidate, and eventually master Latin. In the lack of these, nevertheless, the translation of Aesop's fables into Nahuatl is fit for purpose. An imaginary scenar-

7 For a recent revision of sources that elucidate how Nahua nobility learnt Latin in the mid-sixteenth century, see Laird 20I5. Alcántara Rojas 2013 and Tavárez 2013 provide an insightful discussion of two of the renderings written by Tlatelolco tutors and graduates; the life of St Francis of San Buenaventura and Thomas à Kempis's Imitation of Christ.

io sees a tutor of Latin requesting his pupils to do the exercises proposed by Quintilian for the paraphrase of Aesop, and the first stage is the recreation of the pupils' linguistic and cultural analysis of the text prior to that paraphrase. To begin with, the tutor might have read out the fable in Latin in order to give his students a flare of the text they were about to closely analyse. ${ }^{8}$ Then, they would have discussed terminology that was new to them, stylistic matters, and grammatical issues, such as the presence of unusual verbal constructions or the use of subjunctive versus indicative. To be noted is that this analysis of a classical text in Latin was carried out by native speakers of Nahuatl-an agglutinative language-who stemmed from quite a distinct cultural milieu and geographical New World setting. At times, these factors must have made the task more complicated for them than for native speakers of a Latinate language like Spanish.

The opening fable of the two extant Nahuatl manuscripts, "Quaquauhtentzone yuan coyotl" (the goat and the coyote)—identified by editors Brotherston and Vollmer as "Vulpes et hircus" (the fox and the goat)-, serves as a starting point to speculate on the Nahua pupils' approach. ${ }^{9}$ The story revolves around the fox's

8 The edition that reached the library of Tlatelolco is unknown. Brotherston (1987: I3) suggests that the widely-circulated Aesop fabulae graece et latine or Collectio Accursiana (I479) by Bonus Accursius was the edition consulted by the Nahua translator(s). Only recently, an expert of $\mathrm{Na}$ huatl has created a blog under the name of Ayac, in which s/he puts forward the collection by the German classical scholar Joachim Camerarius (I500-I574); see relevant post at https://nahuatlahtolli.wordpress.com/20I4/og/19/aesops-fables-general-notes/.

9 For the Nahuatl text and its translation into English, based on Kutscher's I96os German version, this study quotes Brotherston and Vollmer's edition as Aesop, I987, followed by page. Ayac has translated some of the fables, offering a more reliable version at http://nahuatlahtolli. wordpress.com/2014/og/29/aesops-fables/. For the source 
trick to spring out of a well in which he is trapped together with a goat, and how, after persuading the goat to help him first, he leaves this one behind. Pupils who were consolidating the fundamentals of Latin might have started by working with their tutor on the meaning of the text sentence by sentence. When discussing the title, they would have recognized the declension, case, gender and number of vulpes and hircus, and outlined the properties of the two animals, attempting to match the fox and the goat with autochthonous species until finally concurring that the goat was to be equated with the quaquaubtentzone, and the fox with the coyote. Whereas the identification of the former rests on physical similarities, that of the latter also has to do with the symbolic or cultural perceptions of the two animals in the European and Nahua cultures. In the same manner as the "cunning fox" sometimes stands for malicious craftiness, for the Nahuas it is the coyote that embodies this sort of astuteness. In this respect, the first chapter of Book XI of Historia universal de las cosas de Nueva España depicts the coyote as "muy sagaz" and "diabólico" or vindictive, because "si alguno le quita la caça [...], procura de vengarse de él, matándole sus gallinas o otros animales de su casa" (Sahagún, I988, II: 682). As for the analysis and word-for-word translation of the first sentence, "vulpes et hircus sitientes in puteum descenderunt" (the fox and the goat were thirsty and went down into a well) (Aesop, I6ı6: 138), the tutor and his pupils would have

text in Latin, this article quotes the Greek monk and scholar Maximus Planudes's (ca. I260-ca. I310) edition, Aesopi phrygis fabulae graece et latine, a compilation from which Accursius imbibed, and which saw numerous reprints from the sixteenth to the nineteenth centuries. The consulted edition was printed in Basel in I6I6 and is cited hereafter as Aesop, I6I6, followed by page. As for the translations from Latin into English this study relies on Gibbs 2009. identified the word that qualified the subject; sitientes, as a present participle, literally translated as "thirsting," "being thirsty." In keeping it as a verbal form, they perhaps put forward "ye amiqui," which is found in the Nahuatl translation of the fable and literally means "already they are dying of thirst." Io For the rest of the sentence, "in puteum descenderunt," they would have continued to establish differences and similarities between Latin and Nahuatl, and probably produced a word-for-word translation by taking Latin grammar as the basis for comparison and understanding of their own language. ${ }^{\text {II }}$ Starting off with the verb, they would have recognized "-erunt" as the third personal plural of the preterit. Figuring out the meaning of the verb would have proven more difficult for a Nahua student than for a Spanish one, to whom the cognate "descender" (to descend) would have come to mind easily. The preposition "in" told the Nahua students that the verb implied some sort of movement towards a place, in this case "in puteum," towards a well. This piece of information together with a hand gesture made by the tutor, signalling a sudden movement downwards, could have led them to translate "descenderunt" as "oncholoque," literally "they jumped” (Aesop, I987: 58).

Having completed a word-for-word analysis of the text in order to gain an in-depth com-

Io "Amiqui," deriving from atl (water) and miqui (to die), is the third person plural, in the present tense, of the verb atniqui (Ruth and Cortés, I968: II6). For another translation of this fable into English, see Ayac's post: https://nahuatlahtolli.wordpress.com/20I4/og/19/aesopsfables-I-the-goat-and-the-coyote/.

II The first extant grammar of the Nahuatl language, the Arte de la lengua mexicana, finished in 1547 by the also tutor of Latin at Tlatelolco Fray Andrés de Olmos, proves that Nahuatl was conceived according to Latin grammatical paradigms. For further reference, see the introduction by Hernández de León-Portilla and León Portilla in O1mos 2002 
prehension, the tutor and his pupils might have come up with a more fluent translation that still abided by the main ideas of the original, which 250 is exemplified in the rendering of the fox's plan. Thus, Planudes's version reads:

si enim rectus steteris, anteriores pedes parieti applicueris, \& cornua partier in anteriorem partem inclinaveris, cum percurrerim ipsa per tuos humeros \& cornua, \& extra puteum illinc exiluerim, \& te postea extraham.

$[Y]$ ou should stand and put your forefeet to the wall, and incline likewise your horns forward. I will then run over through your shoulders and horns and hence leap out of the well. Afterwards I will draw you out. (Aesop, I6I6: I39)

The Nahuatl version maintains the fox's same five-step plan-standing or stretching straight up, putting forefeet against wall, climbing up on back, jumping out, and rescuing the other-as follows:

Ca yntla timotlame lauhcaquetzaz. yuan ym moma caltech ticmamanaz. yuan yn motzontecon ticacouiz. ynic vel micampa veuetztoz moquaquauh. yn neuatl niman mocuitlapan nontlecoz ynic vel nonquiçaz atlacomolco. Auh yniquac oniquiz niman nimitzualanaz.

If you'll stretch yourself straight up and put your forefeet against the wall and lift your head forward so that your horns reach well up, I shall then climb up on your back so that I can get out of the well. And once I'm out I shall help you out! (Aesop, I987: 58-59) ${ }^{\text {I2 }}$

Finally, following Quintilian's suggested exercises for the paraphrase of the original, the

I2 For a more literal translation into Spanish, see Ruth y Cortés, r968: ror; and into English, see Ayac's at https://nahuatlahtolli.wordpress.com/20I4/og/rg/aesopsfables-I-the-goat-and-the-coyote/.

tutor and his pupils could have reinterpreted the moral of the Latin text in their own words, which occurs, for example, at the end of the Nahuatl fable. Planudes's version finishes with this epimythium or final moral: "Fabula significat, sic prudentem virum oportere prius fines altius considerare rerum, deinde sic ipsas aggredi" (the fable means that the prudent man must consider things more carefully before they end, and afterwards thus to attempt them) (Aesop, I6I6: I40). The Nahuatl version, although maintaining the gist of the source text, is slightly paraphrased as: ynyn çaçanillatolli yc timachtilo yn quenin achto monequi ticnemilizque yn tleyn

ticchiuaznequi ynic amo çatepan ipan tiuetziz[que] yn anezcaliliztli, y xolopiyotl.

By this fable we are taught how necessary it is above all to think about what we intend to do, so that we do not later become careless and stupid. (Aesop, 1987: 6o-6r)

In both epimythia the underlying message that comes across is the reconsideration of a decision before taking action. In the Nahuatl text, however, special emphasis is placed upon the consequences of that hasty action; the foolishness and stupidity into which one can fall.

\section{THE TRANSLATION OF AESOP'S FABLES INTO THE NAHUATL LANGUAGE}

Although based on speculation, the former hypothetical scenario can be indicative of the training that the Nahua students received and of their familiarity with Aesop's fables, a textbook that, like in Europe, consolidated their fundamentals of Latin, and which in New Spain helped them acquire the linguistic expertise that was vital to aid friars in conversion duties. In addition, this didactical scenario answers some questions regarding 
the identity of the translator or translators-as it is unknown whether they worked in pairs or whether different fables were commissioned to different translators working under time-pressure to meet a deadline and supervised by a final proofreader. Undoubtedly, their knowledge of Latin and their ability to paraphrase Aesop singles them out as learned Nahuas, graduates or tutors of an institution like Tlatelolco, unique in the teaching of studia bumanitatis in sixteenth-century New Spain, and at the behest of which several religious translations from Latin into Nahuatl were produced, such as Kempis's Imitation of Christ. ${ }^{13}$ What is more, the two worlds in which the translator(s) interacted, the Spanish Christian environment in which they had been schooled and the pre-Hispanic cultural traditions to which they were still bound, transpire in some of their translation decisions. Their interpretation of Aesop's animals is in this sense worth noting. Only a translator with knowledge of European fauna-for example, thanks to the study of natural philosophy in texts like Pliny's Historia naturalis-could have furnished an adequate connection of species in the Old World and the New. ${ }^{14}$ In fact, the translator(s) of the fables show a tendency to associate animals that share a distinctive physical trait,

I3 For a list of Nahua authors and assistants educated in Tlatelolco as well as of some of the works that have been attributed to them, see Kobayashi 1974, and a more recent detailed study by Silvermoon 2007.

I4 Pliny's work is catalogued in the library of the College of Tlatelolco and could have been perused to teach students natural philosophy (Mathes, 1982: 32). Books VIII to XI, on fauna, would have served as a reference for them to fathom out which animals of central Mexico corresponded to those in Pliny's description. The translation from Nahuatl into Spanish of Book XI of Historia universal de las cosas de Nueva España, which Sahagún composed together with some Nahua assistants from Tlatelolco, constitutes another remarkable example of how American zoology was rendered familiar into Spanish. leaving no room for confusion. Based on this direct identification, the dog is translated in fables fourteen, sixteen, twenty-two, twenty-three, and twenty-four as its Nahua equivalence, chichi; the frog, in fables ten, twenty-five, and thirty-seven, as the cuiatl; and the deer, in fables forty-two and forty-three, as the maçatl. A matching belief applied to an animal in both cultures likewise leads to the connection of species, as in the case of the cunning coyote-fox, in fables one, two, three, four, six, and twenty-six; and that of the lion with the fierce "tequani miztli," literally a dangerous or man-eating wild puma, as seen in fables two, twenty-five, twenty-six, twenty-seven, forty-four, and forty-six. ${ }^{15}$

This domestication strategy contrasts with the foreignizing effect that is evidenced in those fables in which the translator(s) choose to maintain the original animal of the Aesopic tradition, that is to say, an animal that did not exist or was unheard of in the New World prior to the arrival of the Spaniards. These are the "cocodrillo" (crocodile) in fable four; the "perdiz" (partridge) in fable five; the "atun" (tuna) in fable nine; the "cauallo" (horse) in fable thirty-eight; and the "asno" (donkey) in fables twenty-six, thirty-two, thirty-eight, and forty-four. The translator(s) of Aesop's fables were cognizant of their audience's unfamiliarity with the tuna and the crocodile and resorted to explanatory translations. In the ninth fable, "Tlatlamaque" (fishermen, from the Latin "Piscatores"), a big tuna flies directly into the fishers' boat just when, having lost hope of catching something, they have decided to return home. The tuna is defined in the Nahuatl fable as "ce

I5 In his Nahuatl-Spanish dictionary the tutor of Tlatelolco Fray Alonso de Molina translates miztli as "leon" (I57r: f. 57v) and in their edition Brotherston and Vollmer opt for jaguar. 
uey michi ytoca atun" (a big fish called Tuna) (Aesop, r987: 80-8I). Similarly, in the "Acuetzpali yuan coyotl" (the crocodile and the coyote, 252 from the Latin "Crocodilus et vulpes"), the crocodile is portrayed as follows:

Centlamantli acuetzpalli muchiua yn vmpa Egipto atlan nemi cenca temamauhti, yn itlachieliz vel yuhquin tzitzimitl itoca cocodrillo yuhquin cuetzpali yc mamaye, auh cenca vey temamauhti yn ixincayo.

Over there in Egypt there is a kind of water-lizard that lives in the water. It is quite terrifying: its appearance is that of a frightful monster. Its name is crocodile. Its feet are like those of a lizard. And it is big, frightening is its bark-like skin. (Aesop, 1987: 68-69)

The translator(s) keep the name of the American species (the acuetzpali) in the title, and in the body of the text they allude to its original counterpart in Aesop's fable. They also include a geographical reference to locate it - in Egypt—, which alerts the readers about the translator(s)' mindset; perhaps familiar with the portrait of the crocodile thanks to Historia naturalis, if not to another source influenced by Pliny, who depicts the reptile in these terms: "The Nilus is inhabited by the crocodile, an ill-disposed creature, four-footed, as dangerous upon land as is upon water" (Pliny, I847-I848, I: 46). In light of Pliny's account, it seems as if the translator(s) generalize the habitat of the crocodile-Egypt instead of its river-, concentrate on its frightening appearance, and liken it to an autochthonous reptile; the also four-footed and with bark-like skin acuetzpali. Another option put forward by Ayac is that the translator(s) were using Camerarius's Latin edition as their source text, which contains this explanatory comment: "Crocodilus Aegyptiacum est animal, tetrum adspectu, atque monstrosum, specie lacer-

tae, cute, rugis et squamis horrida, vastum atque informe" (the crocodile is an animal from Egypt. It has an ugly, even monstrous appearance. It is like a reptile, with horrible, wrinkled, and scaled skin. It is huge and formless) (Aesop, I571: 93). ${ }^{16}$ If compared with the translation into Nahuatl, it appears as if the translator(s) decided to focus on the crocodile's origins and on its monstrous traits, particularly on its peculiar skin.

Regarding the reference to cauallo and asno, which were unknown to the Nahuas in pre-Hispanic times, one cannot completely speak of a foreignizing effect but rather of the translator(s)' intention to portray a new reality. The fables in which the horse and the donkey feature, this time without any clarification, attest to the changing world of the Nahuas, who had been exposed to the mount of the conquistadors and to pack animals from the early years of colonization. In this vein, Brotherston (1987: I7, 21) also indicates that the fables reflect the new economic system brought along by the Spaniards in the form of new types of pastoralism and agriculture. To serve as an example, the fables "Millahcatl yuan ypilhuan" (the farmer and his sons, from "Agricola et filii ipsius") and "Quauhtla çihuamaçatl ihuā xocomecatl" (the hind and the vine, from "Cerva et vitis") are set in a vineyard, a novel kind of cultivation imported by the Spaniards, and which is termed as xocomecamilli, a noun consisting of xocomecatl, a native type of grape vine, and milli or field, cultivated land (Molina, I57r: f. 52r, f. $56 \mathrm{v})$. In the fable of the hind and the vine, it is the moral that contains, nevertheless, the most revealing example of the Old World brought along by the Spaniards. The story narrates how a deer, having hidden behind a vine in an

I6 See Ayac's relevant post at https://nahuatlahtolli. wordpress.com/20I4/o9/26/aesops-fables-4-the-crocodileand-the-coyote/. 
attempt to escape from some hunters, begins to eat the fresh green of the vine, the rustling of which makes them return to kill it. As the deer is dying, it shows contrition in this manner: "huel notlatlacol in ie tzaqua iehica ca amo onicmahuiztili in notepixcauh xocomecatl çan ixco icpa oninen" (I'm suffering entirely because of my own mistake, because I have not honoured my protector the vine! To him I have shown no respect!) (Aesop, I987: 186-I87). The moral of the fable, written immediately afterwards, encapsulates a similar message: "yni çaçanilli techmachtia ca in aquique tlahuelilocaiotl ic quicuepcaiotia teicneliliztli in inpan chihualo hamo huel ixpanpa ehuazque in itetlatzacuiltiliz dios" (This fable teaches us: those who give harm in exchange for kindness which they have received, may not escape the punishment of God) (Aesop, I987: 186-187). Interestingly, Camerarius's version contains no allusion to the Christian God (Aesop r57r: I4I), whereas that of Planudes reads: "Fabula significat, qui injuria benefactores afficiunt, a Deo puniri" (this fable means that those who wrongly blaspheme the benefactors, will be punished by God) (I6r6: 226). If the translator(s) used a Christianized source like Planudes's, their text shows that they remained faithful to the original in that they did not delete the reference to God's merciless demeanour. If, on the contrary, they were reading an edition like Camerarius's, they deviated from the original and rendered the source text by applying a Christian bias to the moral. In any case, what matters here is that the fable is translated into the Nahuatl language for its native speakers and that, at the same time, it has been converted into a religious text, manipulated in order to pass on to them a Christian message.

In the hands of linguistic experts-either graduates or tutors of a Franciscan college like
Tlatelolco, with a depth of experience in translation, paraphrase of source texts, and creation of works for the spread of Christian values and ways of life-it comes as no surprise that their version ended up retaining and also infusing a religious slant. This Christian influence is highlighted in the Bancroft library manuscript. Two of its folios, with the first and the seventeenth fables, display the Christogram IHs, which stands for the first three letters of the name Jesus Christ in Greek, prominently at the top of the page. The monogram, which had increased in popularity during the Medieval Ages, was embroidered in churchmen's vestments and became the recognized iconographical characteristic of prominent preachers like the Franciscan St Bernadine of Siena and the Dominican St Vincent Ferrer, many sermons of whom are catalogued in the library of the College of Tlatelolco (Mathes I982: 55). Remarkably, the Bancroft manuscript contains the Christogram twice, handwritten by two amanuenses-perhaps the translators themselves, although this is obviously impossible to prove-before initiating their task; the first one copying the first sixteen fables and the second one resuming until the end. Whether they had consulted Ferrer's sermons or were familiar with another religious source featuring the Christogram is unknown. What is relevant is that the two amanuenses were personally compelled or commissioned with the religious brief of inserting the Christogram, which perhaps assigned the fables the same religious purpose that they had in Europe; exempla deployed by preachers to capture their audiences' attention and facilitate the understanding of complex dogma.

This alignment of the Nahuatl version of the Aesopic tradition with colonial proselytizing endeavours is endorsed by the open allusions to "Dios" and by the evangelical 
message that many of the translated fables communicate. ${ }^{17}$ For example, in the eighth fable "Nehtolli yn amo vel moneltilia" (the not 254 properly kept promise, or according to Ayac, vows that cannot be fulfilled) an infirm begs the Christian God to cure him and makes him a lavish promise that, knowingly, he will not be able to keep. In the Latin versions of Planudes ("Impossibilia promittens") and Camerarius ("Votum quod soluit non posset") the sick man pledges and commends himself, not to the Christian God, but to the classical pantheon (Aesop, 1616: 153; 1571: 97)..$^{18}$ In other words, if the translator(s) followed one of these or a similar edition, this time it was them who strayed from the original source and turned the divinities into "Dios," whom the sick man addresses in this manner: "totte diose yniquac oniyol, onipatic ca mixpantzinco niquimmanaz macuiltecpantli quaquaueque" (oh our God, as soon as I feel better again and I am well, I shall offer before your face as a sacrifice five times twenty oxen!) (Aesop, 1987: 78-79). Likewise, in the seventeenth fable, "Telpopochtotontin ihuā molchichiuhqui" (the young boys and the cook, or the saucemaker, as suggested by Ayac), the translator(s) transform the Latin version "Adolescentes et coquus" into an example of how the Third Commandment "You shall not take the name of the Lord your God in vain" is contravened. What is more, their rendering comes to showcase that, when interpreting

17 "Dios" appears in fables eight ("Nehtolli yn amo vel moneltilia," the not properly kept promise), seventeen ("Telpopochtotontin ihuan molchichiuhqui," the young boys and the cook), thirty-two ("Asno ihuan chilchiuhqui," the donkey and the gardener), and thirty-eight ("Asno ihuan cauallo," the donkey and the horse).

I8 The Latin text of "Impossibilia promittens," passed down by editors like Émile Chambry (1925-1927) and Ben Perry (1952, I965), also refers to the classical "gods;" see Gibbs, 2008: 249 .

the original, the translator(s) not only applied their Christian bias; they also might have put into practice two exercises that Quintilian (1922: 159) spells out for the paraphrase of Aesop's stories: the delineation of characters (ethologiae) and the writing of maxims or "moral essays" (chriae). Regarding the former, the translator(s) recast the cook and the youngsters as Christian figures, knowledgeable of the Third Commandment, as attested in this dialogue:

auh in iicniuh i huel iehuatl oquichtecnacatl quito nelli nictene hua in itocatzin in dios hamo tle nicpia nacatl auh in molchichiuhqui in oquicac ynteca necayahualiz quimilhui maço Xinechiztlacahuican i nehuatl auh in $\mathrm{tt}^{\circ}$ Dios in anquitlapictenehua itocatzin cuix no huel anquiztlacatizque.

And his friend, the one who had stolen the meat, said to him: "by God's holy name, I have no meat whatsoever!" When the cook had listened to their cheek, he said to them: "You may deceive me, but in vain do you use as witness the great name of our God! Do you think you can deceive him as well?" (Aesop, I987: I02-I05)

The representation of the words uttered by the young boy and the cook, which appears neither in Planudes nor in Camerarius's versions, helps the translator(s) dramatize the original passage. The dialogue intensifies the portrayal of the boy's insolent behaviour and of the cook's Christian moral stance when condemning the boy's lie and insisting in making him query his impious action.

As for the paraphrase of the original by inserting a maxim in the target text, this technique is visible in the Christian bias of the epimythium. Here, the moral of the Nahuatl text and of Planudes and Camerarius's versions acknowledge the power of the Christian 
God. Planudes, in particular, emphasizes his greatness by printing in capital letters the word "deum," as in "DEUM tamen non latebimus" (but to God we are not hidden) (Aesop, I6r6: I69). In the Nahuatl version, the gist of the story also lies on the fact that one might succeed in deceiving others but not God:

Yni çaçanillatolli techtlacahualtia ittechpa iztlacatlatolli in teca necaiahualiztlatolli ihuan in itlapictenehualoca itocatzin $\mathrm{tt}^{\circ}$ iehica ca in iuhqui i muchi quimotztilitica in dios macihui inn aço tlalticpac tlaca amo quitetzacuiltia.

This fable prevents us from deceptive talk, from the deception of others through false words and from using falsely the great name of our God, for it is a fact, that God sees everything, even if punishment does not reach man on earth. (Aesop, 1987: 104-105)

To be noted is that, in opposition to the original, importance is given to the idea of committing a sin against the Third Commandment, "using falsely the great name of our God," and to the punishment that a righteous God will inflict, either on earth or, implicitly, after death. Noticeably, the translator(s) introduce maxims or sentences that could be used in another religious context, for example that of "muchi quimotztilitica in dios" (God is looking at everything), expressing the Christian God's ubiquity.

The Christian message of withstanding sinful behaviour is also manifested in fable thirty-eight, "Asno ihuan cauallo" (the donkey and the horse, from "Asinus et equus"). Having grown jealous of a horse that was greatly honoured and given much fodder, a donkey witnesses how badly injured he is in battle; an outcome that makes him reassess his own position in life and eventually pity the horse. Once again, eyeing the possibility of supplying a fable for doctrinal ends, the translator(s) come up with this Christian moral:

Yni çaçanilli techmachtia ca i macehualti hamo monequi intech moxicozque in tlahtoque ihuan im motlacamati çan munequi ic toiollo pachihuiz in tlein ceceiaca oquimomaquili totecuio Dios iehica ca in tlatoque ihuan motlamati oc çenca miecpa ohuitiliztli quinamiqui.

This fable teaches us: it is not right for subjects to envy their masters and the rich. On the contrary our heart should be content with what our God shares out to each one of us, for the rulers and the rich often have to confront danger. (Aesop, 1987: 174-I75)

In Planudes and Camerarius's versions the moral recommends that the commoners should not envy the rulers and the rich but instead, as stated in Planudes's text, "invidia et periculo in illos consideratis, paupertatem amare" (having considered the envy and the danger [to which they are exposed], to love poverty) (I6I6: 2I8). The Nahuatl text, however, delves into further doctrinal aspects. The belief in predestinationin this case, of human status in life being willed by God-is coupled with a warning against one of the Seven Deadly Sins, that of envy. In a liturgical context, the fable would have fulfilled the function of an exemplum conveying the divine prerogative of social distinction, which, rather than favouring the rulers and the rich, justifies their rank in that at times it burdens them with life-threatening obligations.

The suitability of the forty-seven fables as exempla carrying a Christian message for an indigenous congregation transpires in the collection, and might constitute one of the translator(s) criteria, if not of their commissioner, in the selection of the fables that were rendered and excluded. Thus, several fables adjust very well to counsel against the Seven 
Deadly Sins, among others, fable fifteen "Ycnociuatl yuan yciuatototl" (the widow and her hen, from "Mulier et gallina") against gluttony; 256 fable eighteen "Mococoliani" (the enemies, from "Inimici") against wrath; fable thirty-two "Asno ihu[an] quilchiuhqui" (the ass and the gardener, from "Asinus et hortulanus") against sloth; fable thirty-nine "Tlahtlametl" (the miser, from "Avarus") against greed; fable forty-one "Aiutl ihuan quauhtli" (the turtle and the eagle, from "Testudo et aquila") against lust or desire for something that God has determined not to provide; and fable forty-four "Asno ih[uan] leon tequani" (the ass and the lion, from "Asinus et leo") against pride. Likewise, fables that could have been drawn on in order to warn against reproachable, unchristian conduct and persuade new converts to obey other moral commandments are fable thirty-four "Piltontli ihuan inan" (the lad and his mother, from "Puer et mater"), on the consequences of theft; fables nineteen "Mizton ihuan quiquimichtin" (the cat and the mice, from "Felis et mures") and forty-five "Ichcapixqui ihuan coiotl" (the shepherd and the coyote, from "Pastor et lupus"), on the irreversible characteristics of deceitful, evil people; and fable thirty-one "Cocoxqui ihuan ticitl" (the sick man and the doctor, from "Aegrotus et medicus"), on the power of false appearances and on liars with smooth and seductive talk. Finally, there are also fables that could be classified as exempla encouraging hope and faith in times of duress, such as fable thirty-seven "Cicihti ihuan cuicuia" (the hares and the frogs, from "Lepores et ranae"), as well as fables that commend the experience of trouble and mortal danger as human lessons to become wiser in life and confront future perilous circumstances, such as fables twenty-three "Chichi ihuan cuitlachtli" (the dog and the wolf, from "Canis et lupus") and thirty-five "Ichcapixqui ihuan

hueiatl (the shepherd and the sea, from "Pastor et mare"). The latter, in particular, tells the story of a merchant who loses all his cargo in a shipwreck. This event changes him into a cautious man, able to foresee jeopardy in situations that at first sight seem harmless. This fable, as the moral reads: "techmachtia ca in tlein tecoco tetolini ceppa topan omochiuh technemach maca i çatepan" (teaches us [that] whatever we have experienced as misfortune and unhappiness will later on be a warning to us) (Aesop, 1987: 174-175).

The previous fable lends itself to ponder on the different Nahuatl-speaking audiences to which the Aesopic tradition was aimed. There is the reader, a literate Nahua who would have reflected on the edifying words of the moral; the user, most likely a churchman or his Nahua aide, who consulted the collection when looking for an exemplum that accorded to the message that was to be transmitted to actual listeners; and the members of this audience, who in the best case scenario paid attention to the message. As a matter of fact, it is precisely this potential oral performance that stands out in some of the Nahuatl fables. In an attempt to meet the educational, socially-entertaining, and proselytizing goals of the fables, and at the same time restoring the Aesopic tradition back to its aural origins, the translator(s) reconcile their classical studies with the Nahua rhetorical tradition with which they were acquainted. Thus, as previously observed, they tend to paraphrase the fables by falling back upon the delineation of characters (ethologiae)—one of the exercises suggested by Quintilian-, inserting discourses and dialogues. In doing so, they emulate the rhetorical style that is reflected, for instance, in their buehuetlabtolli. These "ancient words" were speeches, prayers, and salutations that, prior to the arrival of the Spaniards, had been mostly 
delivered by priests, members of the aristocracy, merchants, and midwives, who conveyed their religious, moral, and social concepts in an alluring and persuasive style. In the sixteenth century, the codification of these buehuetlabtolli was directed by friars like Olmos and Sahagún, both teachers of Latin at the College of Tlatelolco and both well-disposed to the possibility of emulating, to a certain degree, the style of the buebuetlabtolli in their Christian sermons. ${ }^{19}$ In Sahagún's case, he and his assistants copied many of the oral elements that are traced in the buebuetlahtolli-vocatives, reverential forms, questions, explanatory comments, repetitions, and fixed phrases-in passages of doctrinal works like Adiciones, apéndice a la postilla y exercicio quotidiano (1993: 105, II7; Bustamante García, I989: 704-707)..$^{20}$ In the case of the fables in Nahuatl, the translator(s) must have expected that all these rhetorical characteristics would capture the Nahua auditors' attentionaccustomed to hearing them in public events and private rituals, such as in prayers to gods, admonitions given by parents to their youngsters, and ceremonial conversations between midwives and the family of a newborn. In other words, the translator(s) were familiar with the imitation of Nahua rhetoric during the writing of new works and translations, and they might

19 Olmos's collection was edited and partially translated by Fray Bautista Viseo in I6or and Sahagún's is included in Book VI of Historia universal de las cosas de Nueva España. With the number of studies on the huehuetlabtolli and their doctrinal applicability being vast, recommended reading is the comprehensive work by Ruiz Bañuls 2009 . Interestingly, the translator(s) regarded the fables as çaçanillatolli, a compound word consisting of tlabtolli, words or discourse, and çaçanilli, defined by Molina as "consejuelas para hazer reyr" (I57r: f. I3v).

${ }_{20}$ For further reference on sixteenth-century friars and their assistants' ability to borrow the indigenous rhetorical style for Christian purposes, see Burkhart's I989 seminal study. have become conversant with this practice by working for or together with members of the Tlatelolco community.

Brotherston (1987: 3I, 1992: 315) indicates 257 the striking presence of the Nahua rhetorical tradition throughout the fables, and stresses how the laconic reported speech of the Latin text-as found in Planudes, Camerarius and Accursius's collections-is replaced in its translation into Nahuatl with direct speech in the form of dialogues and discourses, which, delivered by main characters, are reminiscent of the buehuetlabtolli. Fable forty-six "Leon tequani ihuan cuitlachtli" (the deadly lion and the wolf, from "Leo et lupus") illustrates the manner in which the indigenous conversational style of the buebuetlabtolli is transferred to the fables. In the original story a lion king, having grown old and sick, receives the homage visit of all his animal subjects but for that of the fox, a mistake that the wolf, her staunchest enemy, seizes as an opportunity to denounce the fox's disrespect towards the lion. Having heard how the wolf has tried to put her at loggerheads with their master, the fox serves a cold revenge. She claims to have been travelling all around the world in search of a remedy for the lion's illness, which happens to be the skin of a living wolf. Whereas in Planudes and Camerarius's versions the dialogues held by the wolf, the lion, and the fox are mostly reported in indirect speech and limited to a couple of sentences, in the Nahuatl text the translator(s) dramatize the passage with compelling direct speech. In the Latin source, the wolf is said to complain to the lion in this manner: "Lupus [...] accusabat apud leonem vulpem, quasi nihili facientem suum omnium dominum, \& propterea neque ad visitationem prosectam" (the wolf accused the fox to the lion of doing nothing for his master and therefore of not having come for a visit) (Aesop, 1616: 236). 
In the Nahuatl passage, the accusation levelled by the wolf against the fox, which is represented by the coyote, reads: "tlatohuanie tla ic xicmotili 258 in inepohualiz coiotl in hamo tehua ohualla in mitzmotlapalhuiz ca nelli amo tleipan mitzmotilia" (Oh, lord! Take note of the haughtiness of the coyote! He did not come with the others in order to greet you! Truly, he does not value you much!) (Aesop, 1987: 196-197). In the same manner as in a buebuetlabtolli, the translator(s) insert the vocative tlatohuanie (oh, lord), and two parallel sentences transmitting the same idea; that the coyote is not willing to pay his respects. Similarly, the Nahuatl version transforms the reported narrative of the dialogue between the lion and the fox into a lively exchange of words between a disgruntled leon tecuani or miztli tequani and a humble coyote. The former's complaint reads: "can oticatca nocne cuix amo titlachia in nican omoçenquixtique noteicahuan manenemi nechtlapaloco auh çan tiio in amo nimitzita" (Where have you been miserable one? Did you not notice that all together my younger brothers, the four-footed creatures, have appeared here to greet me? But I did not see you amongst them!) (Aesop, 1987: 196-197). This time the translator(s) mimic the Nahuas' rhetorical style by introducing the vocative nocne (miserable one), two consecutive questions, and an epithet for noteicahuan (my younger brothers); manenemi (four-footed creatures). In turn, the coyote begins his reply with "tla oc ihuian xinechmocaquiti totecuioe" (have the goodness to listen to me without anger, oh our master!) (Aesop, 1987: I98-199); a deferential exclamation that continues to resemble the Nahuas' oral tradition.

As for the paraphrase of the Latin text by adding a speech or a discourse that, echoing the huebuetlabtolli, calls attention to some moral values or pieces of advice, there exist several

fables in which a leading animal gathers his companions to warn or teach them a lesson. A salient example is fable thirty-six, "Quetzaltototl ihuan toznene" (the queztal-bird and the parrot, from "Pavo et monedula;" the peacock and the jackdaw). Here, a variegated group of birds are holding council in order to elect their new leader, when the proud peacock-notably turned into the also beautifully-feathered quetzal-demands the rank for himself on the grounds of his majestic display of colours. The jackdaw, embodied in the Nahuatl version by an eloquent parrot, intervenes to make them all reflect on their decision. In the Latin sourcevery brief in both Planudes and Camerarius's editions-, the jackdaw brings the story to an end with this query: "si, te regnante, Aquila nos persequi agressa fuerit, quomodo nobis opem feres?" (if once you [the peacock] are our king, the eagle were to attack us, how will you bring assistance to us?) (Aesop, I6I6: 2II). In the Nahuatl fable the translator(s) visibly expand the parrot's speech by writing:

iequinnonotzaquimilhuitlaxicmocaquitican totecuiohuane in amiquecholhuā ipalnemoani, intla iehuatl anquimotenehuilia totlatocauh iez i nican icac quetzaltototl auh intla quenami techiaochihuaz quauhtli quexquich in itlapalihuiz oncatqui cuix huel quinamiquiz auh iehica i nehuatl iuh niquita iehuatl technequi tiquixquetzazque in totlatocauh iez quauhtli.

He warned them, he spoke to them: "Be so kind as to listen, oh our lordships. Oh you Quecholli [flamingos] of 'the one through whom we live'. If this is the one whom you nominate to become our head, he who stands here, the Quetzal,- - what shall be his strength to us if the eagle makes war on us one day? Would he be able to stand up against him? For this reason I for my person am of the 
opinion: he, the eagle, is the one we are in need of, him we should appoint as our leader, our leader must be the eagle! (Aesop, 1987: I66-I67)

The speech consists of vocatives like totecuiobuane (our lordships), repetition, and several sentences that demand the hearers' attention, once again in the form of imperatives and questions. The passage is likewise rich in the expression of Nahua cultural knowledge. First, the epithet "amiquecholhuā ipalnemoani"-you are the flamingos of the one through whom we live or Live Giver) - echoes the pre-Hispanic belief in the flamingo as a messenger of the divinities, which is found in Nahua songs like those collected in the anonymous Cantares mexicanos (1985: 186-187). Second, the end of the paragraph makes the thought-provoking claim that it is the powerful cuaubtli (eagle) that should be appointed lord of the birds. In Planudes and Camerarius's texts the eagle is only mentioned in order to disclose the inadequacy of the peacock, with the moral advocating for a leader not on the basis of his appearance but of his bravery and wisdom. In the Nahuatl version, nevertheless, the translator(s) make their own interpretation of the original by "electing" the eagle. Their choice is far from arbitrary. For them this bird of prey, an epitome of fearlessness in battle, constituted a strong symbol of identity, for it had been an eagle perched on a nopal cactus and holding a rattlesnake that had indicated a Nahua religious leader where the capital of their ancestors' empire had to be founded.

\section{CONCLUSION}

This vision of the cuaubtli as a towering leader exemplifies the influence that, as contended by Brotherston (1987, 1992), the pre-Hispanic culture exerted upon the Nahua translator(s) of Aesop's fables. This article, nevertheless, has been concerned as much with the translator(s)' Nahua mindset as it has with their religious brief, arguing for the possibility that they had 259 been commissioned by churchmen who needed exempla for their religious communications with the indigenous population, and that, for this reason, they set out to write a Christian biased translation. It is still impossible to claim that the former students and later assistants of friars like Olmos and Sahagún authored the translation of Aesop's fables, but they do appear to fit the bill as they lived at the interface of two worlds, experiencing the symbiosis and cultural synergy that institutions like the College of Tlatelolco generated. As "trilingual" members of Tlatelolco they stand out because of their linguistic mastery in the translation of texts from Latin into Nahuatl and because, during the creation of religious works in Nahuatl, they aided the friars in the emulation of their pre-Hispanic rhetorical style. For example, at a time during which their ancestors' cultural conceptions were being obliterated, their involvement in the composition of texts like Historia universal de las cosas de Nueva España-roughly speaking, an encyclopaedia on the world of the Nahuas that records many of their ritual practices and beliefs as well as their oral style-offered them an unrivalled setting in which to learn about their disappearing culture, to study, and to internalize the main elements that defined their ancient rhetoric. In connection with this work, it is interesting to note that the first chapters of Book $\mathrm{XI}$, on fauna, contain a few exempla as well as references to animal qualities that the Nahuas attached to human beings. All these, together with other stories that Sahagún understood as fables, as in the case of "the fable of the rabbit and the moon" of Book VII, were codified with 
a view to being deployed in the transmission of the Christian faith (Sahagún, I950-I982: 66, 87). A relevant example is that of a "lascivious" 260 snake, the mazacoatl, chosen by Sahagún and Bautista Viseo when reprehending unmoral conduct in two of their sermons (Sahagún, I993: IIO, II3; Alcántara Rojas, 2005: 39I).

This article has also attempted to suggest a skopos or translation purpose and account for the origin of some translation decisions-a more thorough display of translation techniques is only possible after having identified the original source, which goes beyond the scope of this study. Even in the case that the translator(s) used an already Christianized source of Aesop's fables, the fact that they decided to maintain and even expand the religious interpretations seems to be telling us that the fables were rendered to transfer Christian dogma and beliefs. A translator who had merely sought to render the fables for the entertainment of a Nahua audience would have seen no point in introducing Christian references. Conversely, a translator who had been commissioned to transform the fables into engaging and proselytizing çaçanillatolli-the Nahuatl equivalence for "fables" - knew how to negotiate meanings; how to make the fables sound as religious texts with a moral to learn and at the same time how to catch the indigenous listeners' attention.

Questions as regards the members of this Nahua audience and the use of the two surviving manuscripts before reaching the Biblioteca Nacional and the Bancroft library linger on. Both manuscripts descend from a Christian context, but the one in the Bancroft library, with the hand-written IHS in two of its pages, is most likely to have been employed in proselytizing endeavours. Whether or not the fables indeed served as religious exempla still remains to be proven, for instance by searching for them

in extant doctrinal works written in the Nahuatl language. The manuscript of the Biblioteca Nacional, with the Christian slant but without the IHs inscription, might have been drawn on in a wider context. This differentiation does not exclude the possibility that the two manuscripts, together with other copies, circulated amid learned Nahuas who, adjusting the fables as they saw fit, would have told them in private meetings and public gatherings. The existence of other Nahuatl fables, some of which were compiled by the Mexican sociologist Pablo González Casanovas in Cuentos indigenas (I946), might reveal an association with the Aesopic tradition and perhaps a popular adaptation that, with the passing of the centuries, the general public might have made of it.

RECIBIDO EN JULIO DE 2014 ACEPTADO EN DICIEMBRE DE 2014 VERSIÓN FINAL DE MARZO DE 2015

\section{REFERENCES}

Aesop. (I6I6). Aesopi phrygis fabulae graece et latine, cum aliis quibusdam opusculis quorum indicem sequens pagella indicabit [edited by Maximus Planudes], Basilea: Ioan Iacobi Genathi.

Aesop. (1571). Fabulae Aesopicae plures quingentis, et aliae quaedam narrationes [edited by Ioachim Camerarius], Lugduni: Ioan Tornaesium.

Alcántara Rojas, B. (2005). «El dragón y la mazacóatl: Criaturas del infierno en un exemplum en náhuatl de fray Ioan Baptista», Estudios de Cultura Nábuatl, 36, 383-422.

Alcántara Rojas, B. (20I3). «Evangelización y traducción. La vida de San Francisco de Buenaventura vuelta al náhuatl por fray Alonso de Molina», Estudios de Cultura Nábuatl, 46, 89-158.

Anderson. A. J. O. (1993). «Introduction». Bernardino de Sahagún's Psalmodia Christiana, Salt Lake City: University of Utah Press, xv-xxxv.

Brotherston, G. (1987). «Aesop auf Aztekisch. Aesop 
in Aztec». See Kutscher, G., G. Brotherston \& G. Vollmer (eds.), II-49.

Brotherston, G. (1992). Book of the Fourth World: Reading the Native Americas through their Literature, Cambridge: Cambridge University Press.

Burkhart, L. M. (1989). The Slippery Earth: NahuaChristian Moral Dialogue in Sixteenth-Century Mexico, Tucson: University of Arizona Press.

Bustamante García, J. (1989). La obra etnográfica y lingüistica de fray Bernardino de Sahagún, Madrid: Universidad Complutense.

Bustamante García, J. (1990). Fray Bernardino de Sahaguin: Una revisión crítica de los manuscritos y de su proceso de composición, México: Universidad Nacional Autónoma de México.

Cantares mexicanos. (1985). Cantares mexicanos: Songs of the Aztecs, Bierhorst, J. (ed.), California: Stanford University Press.

Ciccolella, F. (2008). Donati Graeci: Learning Greek in the Renaissance, Leiden: Brill.

Garibay Kintana, Á. M. (1953-1954). Historia de la literatura nábuatl, 2 vols, México: Porrúa.

Gibbs, L. (ed.). (2008). Aesop's Fables: A New Translation, Oxford: Oxford University Press.

Gibbs, L. (ed.). (2009). Aesop's Fables in Latin: Ancient Wit and Wisdom from the Animal Kingdom, Mundelein, Illinois: Bolchazy-Carducci Publishers.

Gibbs, L. (ed.). (2010). Mille Fabulae et Una: IооI Aesop's Fables in Latin, Morrisville: Lulu.

Gómez Canedo, L. (I98I-I982). «Viejas bibliotecas de México (un informe de I662-I664)», Boletin del Instituto de Investigaciones Bibliográficas, 67-73.

González Casanova, P. (1946). Cuentos indigenas: Edición bilingüe nábuatl y española, México: Universidad Nacional Autónoma de México.

Kobayashi, J. M. (1974). La educación como conquista: Empresa franciscana en México, México: El Colegio de México.

Kutscher, G., G. Brotherston \& G. Vollmer (eds.). (1987). Aesop in Mexico: Die Fabeln des Aesop in aztekischer Sprache. A sixteenth-Century Aztec Version of Aesop's Fables, Berlin: Gebr. Mann Verlag.

Laird, A. (2015). «The Teaching of Latin to the Native Nobility in Mexico in the mid-1550s: Contexts, Methods, and Results», Learning Latin and Greek from Antiquity to the Present, Archibald, E. P., W. Brockliss, \& J. Gnoza (eds.), Cambridge: Cambridge University Press, II8-I35.
Mathes, M. (1982). Santa Cruz de Tlatelolco: La primera biblioteca académica de las Américas, Mexico City: Secretaría de Relaciones Exteriores.

Molina, Fray A. de. (157I). Vocabulario en lengua castellana y mexicana y mexicana y castellana, facsimile with introduction by León-Portilla, M. (1970), México: Porrúa.

Murphy, J. J. (1987). «Introduction», Quintilian on the Teaching of Speaking and Writing: Translations from Books One, Two, and Ten of the Institutio oratoria, Murphy, J. J. (ed.), Carbondale \& Edwardsville: Southern Illinois University, ix-xlviii.

Olmos, Fray A. de. (2002). Arte de la lengua mexicana, Hernández de León-Portilla, A. \& M. LeónPortilla (eds.), México: Universidad Nacional Autónoma de México.

Orme, N. (2006). Medieval Schools: From Roman Britain to Renaissance England, New Haven: Yale University Press.

Pliny, the Elder. (I847-I848). Natural History in Thirty Seven Books, Vol. I, Holland Ph. (tran.), Wernerian Club (ed.), London: George Barclay.

Quintilian, M. F. (1922). De institutione oratoria, Butler, H. E. (tran.), London: Heinemann.

Ríos Castaño, V. (2014). Translation as Conquest: Sahagún and Historia universal de las cosas de Nueva España, Madrid-Frankfurt: Iberoamericana-Vervuert.

Ruiz Bañuls, M. (2009). El huehuetlatolli como discurso sincrético en el proceso evangelizador novohispano del siglo XVI, Roma: Bulzoni.

Ruth y Cortés, A. (I968) «Fábulas de Esopo [...]», Congreso internacional de americanistas, XI Reunión en México, del I5 al 20 de octubre de 1885 , Wieswaden: Lessingdrukerei, Ioo-II6.

Sahagún, Fray B. de. (1950-I982). Florentine Codex: General History of the Things of New Spain, Anderson, A. J. O. \& C. E. Dibble (eds. \& trans), I2 vols, Salt Lake City: University of Utah Press.

Sahagún, Fray B. de. (I988). Historia general de las cosas de Nueva España, García Quintana, J. \& A. López Austin (eds.), 2 vols, Madrid: Alianza.

Sahagún, Fray B. de. (1993). Adiciones, apéndice a la postilla y ejercicio cotidiano, Anderson, A. J. O. (ed. \& tran.), México: Universidad Nacional Autónoma de México.

Salisbury, J. (2012). The Beast Within: Animals in the Middle Ages, Hoboken: Taylor and Francis. 
Silvermoon. (2007). The Imperial College of Tlatelolco and the Emergence of a Nerw Nahua Intellectual Elite in New Spain (1500-I760), Duke University, Doctoral Dissertation.

262 Tavárez, D. (20I3). «Nahua Intellectuals, Franciscan Scholars, and the Devotio Moderna in Colonial Mexico», The Americas, 70, 203-235.
Taylor, L. (1992). Soldiers of Christ: Preaching in Late Medieval and Reformation France, Oxford: Oxford University Press.

Vollmer, G. (1987). «Handschriften und Edition der aztekischen Aesop-Texte. Manuscripts and Edition of the Nahuatl text», Kutscher, G., G. Brotherston \& G. Vollmer (eds.), 206-242. 